\title{
Article
}

\section{Global Supply Chains in Response to COVID-19: Adopting a Real Options Mindset}

\author{
Luis A. Perez-Batres ${ }^{1}$, Len J. Treviño ${ }^{2}$ \\ ${ }^{1}$ Central Michigan University, USA, ${ }^{2}$ Florida Atlantic University, USA \\ Keywords: real options, black swans, global supply chains, covid-19, regional integration \\ https://doi.org/10.46697/001c.17884
}

\section{AIB Insights}

Vol. 20, Issue 3, 2020

Businesses and governments may have been overconfident in their ability to react efficiently to black swan consequences. COVID-19 levied unforeseen isolation and border closings threatening the survival of global supply chains and the bankruptcy of governments and organizations alike. As a response to this challenge, our proposal takes a real options approach to mitigate supply chain disruptions by developing regional partnerships outside of densely populated areas. Its inherent novelty is twofold: (1) it anticipates survival uncertainties by securing the continued production of goods and services worldwide and (2) it recognizes a change in the relationship's dynamic between global and regional actors.

Societies have learned to anticipate the repercussions of wide-reaching natural and human-made catastrophes for centuries. For example, in response to severe economic depressions, the English and American governments established the Poor Laws of 1601 and the Social Security Act (1935), respectively, to ease the foreseeable economic and costly consequences of unemployment, illness, and disability. COVID-19 shone a spotlight on society's inability to function normally during the most recent "black swan" (Taleb, 2007). ${ }^{1}$ Indeed, it has led to reduced trust in governments, amplified the need for financial and occupational security, and threatened the very survival of millions. The great global financial crisis of 2008 cost the United States more than $\$ 2$ trillion. The current COVID-19 crisis has been even more devastating, with recent estimates of up to $\$ 15$ trillion in economic losses and nearly 1 million fatalities worldwide. ${ }^{2}$ Even more problematic, international governments and organizations still appear to be reacting to black swan aftershocks rather than anticipating them. In this article, we call on governments and organizations alike to add a new protocol to their arsenal of governance and managerial practices, namely a real options mindset that can mitigate the costs of future black swan consequences of this magnitude.

\section{FAT TAILS, COVID-19, AND BLACK SWANS}

Lowenstein (2000) concluded that when geniuses fail, it is because they did not respect the "fat tails" of the bell curve or the normal distribution of occurrences. Stated differently, few acknowledge that adverse effects will inevitably occur or that they have the capacity to wipe out entire organizations and decimate countries (i.e., all the positive years within the bell curve). This admonishment is clearly exemplified in the current COVID-19 crisis, which has left a wave of business closures in its wake. Moreover, this rationale is consistent with recent international business experiences, such as the international exchange of goods and services that did not account for the possibility of sudden and profound disruptions.

The COVID-19 global pandemic can be considered a black swan because its worldwide consequences were extremely uncommon, consequential, and hard to predict (an unknown unknown). ${ }^{3}$ Indeed, few could have imagined the forced isolation measures resulting from border closures and widespread shelter-in-place orders that taxed the efficacy of supply chains worldwide. Examples of disruption in global supply chains include manufacturing shutdowns in the beef industry, an inability to produce critical personal protective equipment, such as N95 masks, and shuttered distribution networks in high-density population areas throughout the world.

Yet we observe that current corporate structures assume a flat business world able to overcome the fat tails problem. However, given the implications of black swan phenomena, it is necessary to recalibrate the cost of future shocks even beyond the risks associated with gaussian fat tails. The po-

1 According to Taleb (2007), a black swan is defined by three attributes. It is an (1) outlier event of (2) extreme influence and (3) impossible to predict, as it falls outside the historical statistical record.

2 Mukunda 2018; Smit et al. 2020; www.worldmeters.com

3 Even though our "fat tails" reference draws attention to the risks associated with adverse events, we also imply that these "fat tails" can extend beyond the expectations derived from a normal distribution and reach into the uncertainty realm. In a way, preparing for unknown events that can profoundly affect the worldwide supply chain is a call to prepare for the consequences of "unknown unknowns" occurring in “Extremistant” (terms developed by Taleb, 2007).

4 Repko, 2020; O’Brien, 2020; Yeung, 2020 
Table 1. Planning for Possible Black Swan Consequences Disrupting the Global Supply Chain (Ordinary Risk Management vs. Risk Management and Black Swan Consequences)

\begin{tabular}{|c|c|c|c|c|c|c|}
\hline $\begin{array}{l}\text { Planning } \\
\text { Assumption }\end{array}$ & $\begin{array}{l}\text { Source of } \\
\text { Challenge }\end{array}$ & $\begin{array}{l}\text { Optimal } \\
\text { Business } \\
\text { Model / } \\
\text { Objective } \\
\text { (under } \\
\text { globalization } \\
\text { era policies) }\end{array}$ & $\begin{array}{l}\text { Hedging } \\
\text { Focus }\end{array}$ & $\begin{array}{l}\text { Implementation } \\
\text { Vehicles }\end{array}$ & $\begin{array}{l}\text { Successful } \\
\text { Outcome (if } \\
\text { adverse } \\
\text { outcome } \\
\text { occurs) }\end{array}$ & $\begin{array}{l}\text { Successful } \\
\text { Aggregate- } \\
\text { Level } \\
\text { Impact }\end{array}$ \\
\hline $\begin{array}{l}\text { Ordinary Risk } \\
\text { Management } \\
\text { (future } \\
\text { replicates } \\
\text { past) }\end{array}$ & $\begin{array}{l}\text { Known - e.g., } \\
\text { economic } \\
\text { downturn, } \\
\text { theft }\end{array}$ & $\begin{array}{l}\text { Comparative } \\
\text { Advantage / } \\
\text { Profit } \\
\text { Maximization }\end{array}$ & $\begin{array}{l}\text { Insurance/ } \\
\text { Financial }\end{array}$ & $\begin{array}{l}\text { Insurance } \\
\text { Policies/ } \\
\text { Financial } \\
\text { Derivatives }\end{array}$ & $\begin{array}{l}\text { Repayment } \\
\text { of lost } \\
\text { income or } \\
\text { assets for } \\
\text { individual } \\
\text { organization }\end{array}$ & $\begin{array}{l}\text { Marginal - } \\
\text { other } \\
\text { individual } \\
\text { firms can } \\
\text { meet } \\
\text { community } \\
\text { demand }\end{array}$ \\
\hline $\begin{array}{l}\text { Risk } \\
\text { Management* } \\
\text { and black } \\
\text { swan } \\
\text { consequences }\end{array}$ & $\begin{array}{l}\text { Unknown - } \\
\text { system wide } \\
\text { disruption } \\
\text { (anticipates } \\
\text { consequence) }\end{array}$ & $\begin{array}{l}\text { Comparative } \\
\text { Advantage } \\
\text { Hybrid / } \\
\text { Profit } \\
\text { Maximization } \\
\text { \& Survival }\end{array}$ & $\begin{array}{l}\text { Real } \\
\text { Options }\end{array}$ & $\begin{array}{l}\text { Flexible choices } \\
\text { to expand, } \\
\text { abandon, switch } \\
\text { - e.g., regional } \\
\text { webs of supply } \\
\text { chain nodes }\end{array}$ & $\begin{array}{l}\text { Individual } \\
\text { members of } \\
\text { global } \\
\text { supply } \\
\text { chains keep } \\
\text { operating }\end{array}$ & $\begin{array}{l}\text { Large - } \\
\text { May result } \\
\text { in global } \\
\text { system } \\
\text { survival }\end{array}$ \\
\hline
\end{tabular}

*Planning in addition to (not instead of) ordinary risk management assumptions

tential expansion of a firm's international boundaries to include regional partnerships outside of densely populated large urban areas, or megacities, would mitigate eventual supply chain disruptions threatening global connectedness. Moreover, these regional partnerships would enhance an organization's ability to meet the regional (local) demand for products and services despite global connectedness disruptions during such critical situations. Table 1 provides a useful implementation guideline, supported by our insights and proposition on how to plan for black swan events, stated below. Likewise, Table 2 depicts an alignment of interest rationale between state or country governments and global supply chains, also explained below in the incentives section.

\section{FINANCIAL HEDGING}

How do we manage organizational operations with the least amount of disruption during a black swan event? Was this probing question on the minds of government and corporate leaders before the onset of COVID-19? Although few selected this choice, one might think about financial options as part of a viable hedging strategy. The benefit lies in the difference between the costs of financial hedging against the impossibility of operating a business due to an unforeseeable event. A notable example is that of the AllEngland Tennis Club; for the past 17 years, Wimbledon paid for an insurance policy to cover against cancellation losses due to a worldwide pandemic. They will receive $£ 114$ million amid the current contingency. ${ }^{5}$

In this instance, Wimbledon was among the very few organizations that hedged for such an event and mitigated the black swan's financial consequence. However, if financial hedging against black swans consequences were to be- come commonplace, would insurers (or other financial institutions) withstand such calamities, one where $40 \%$ or more of their policies would demand payment within a single quarter? It would be unlikely, as total system failure (or close to it) is not priced into current risk parameters. It is also worth noting that financial hedging can only offer money (e.g., for income loss or asset replacement). Yet it cannot provide a physical infrastructural alternative for businesses to continue their operations during a pandemic.

\section{RISK $\neq$ UNCERTAINTY}

In ordinary circumstances, financial hedging is also limited, insofar as it mainly operationalizes risk rather than uncertainty. We have learned how to calculate risk fairly accurately by studying the probabilities of future events. Yet we forget that our ability to do so depends on the pattern of repetition of a well-known historical record. In contrast, we often ignore possible events (i.e., uncertainties) outside of these records (Epstein, 1999). For example, during the great financial crisis of 2008, the financial system ignored the possibility of a system-based mortgage default, as if it had never occurred. Indeed, when Dr. Michael Burry, the famous founder and manager of the hedge fund, Scion Capital, approached several Wall Street executives to invest in credit default swaps two years before the crisis, they were surprised. Eventually, Burry was proven right and large issuers of mortgage-back securities, including Bearn Stearns and Lehman Brothers, went bankrupt while the entire financial system suffered huge losses (Lewis, 2011). Likewise, in April 2020 , oil futures prices were negative for the first time in trading history, further demonstrating the limits of financial hedging.

A similar bias (i.e., ignoring uncertainties) is present in 
Table 2. Alignment of Incentives (Ordinary Risk Management vs. Risk Management and Black Swan Consequences)

\begin{tabular}{|l|l|l|}
\hline $\begin{array}{l}\text { Planning } \\
\text { Assumption }\end{array}$ & Main Gov. Objectives (Related to Large Orgs.) & GSC Objectives \\
\hline $\begin{array}{l}\text { Ordinary Risk } \\
\text { Management } \\
\text { (future } \\
\text { replicates } \\
\text { past) }\end{array}$ & $\begin{array}{l}\Delta \text { Job Creation - e.g., tax breaks to attract large GSC, } \\
\Delta \text { Tax Base/Income, Securing the availability of basic } \\
\text { products (e.g., food) and services }\end{array}$ & $\begin{array}{l}\text { Profit Maximization via: Economies of Scale, Access } \\
\text { to human resources, Tax breaks, Enhanced global } \\
\text { logistics }\end{array}$ \\
$\begin{array}{l}\text { Risk } \\
\begin{array}{l}\text { Management* } \\
\text { and black } \\
\text { swan } \\
\text { consequences }\end{array}\end{array}$ & $\begin{array}{l}\Delta \text { Job Creation - e.g., tax breaks to attract large GSC, } \\
\Delta \text { Tanemployment pay), Avoiding GSC disruptions } \\
\text { resulting in income tax loss, Avoiding the scarcity of } \\
\text { basic products (e.g., food) and services }\end{array}$ & $\begin{array}{l}\text { Profit Maximization Hybrid via: Suboptimal } \\
\text { economies of scale \& enhanced survival, Access to } \\
\text { human resources through regional development, Tax } \\
\text { breaks \& avoiding disruption, Suboptimal global } \\
\text { logistics \& superior regional embeddedness }\end{array}$ \\
\hline
\end{tabular}

*Planning in addition to (not instead of) ordinary risk management assumptions

current international business practices. Governments and corporations had assumed international trade to be close to frictionless; according to risk-based scenarios, there was no basis for thinking otherwise. However, Desilus (2020) noted that global supply chains quickly became compromised due to COVID-19. Their overdependence on internationally based suppliers, which used to provide them with opportunity cost advantages and maximum profitability across countries and regions, has now threatened their very survival.

\section{REAL OPTIONS HEDGING}

Financial hedging (e.g., calls, puts, forwards) might not be the appropriate vehicle to mitigate black swan catastrophes. On the other hand, a real options approach provides its holders with an actual physical choice (a hedging alternative), to expand, abandon, or switch. For instance, the growing worldwide market for home standby generators aptly demonstrates a consumer's capacity to exercise the real (physical) option to switch by circumventing power suppliers amid temporary grid failures. Thus, similar to the real options logic illustrated herein to withstand grid failure contingencies, we propose governments and corporations utilize real options in response to contingency failures stemming from regular supply chain ("power grid”) disruptions.

As a result of the globalization era's policies allowing the world to be more interconnected and interdependent, global supply chain networks have successfully followed a comparative advantage model. This model emphasizes developing distinct competencies in different geographic areas while simultaneously lowering opportunity costs. However, the COVID-19 pandemic has levied forced isolation and border closings consequences that have threatened its efficiency and the global value chain system's very survival. Therefore, to elevate the likelihood of organizational survival, we propose a physical hedging supply chain option that allows worldwide suppliers to continue operations during black swans of similar consequences. For this proposal to succeed, there is a need to create the physical capacity (a real option) to "power" global supply chain operations during extreme isolation measures. In concrete terms, governments and organizations need to develop regional sourcing by building multiple webs of "essential" supply chain nodes in low-density population areas worldwide (e.g., locations less likely to be severely affected by pandemic spread).

\section{WHY REDESIGN TO SOURCE REGIONALLY - JUSTIFICATION AND MOTIVES}

\section{LOWER POPULATION DENSITY (LOCATION)}

In contending that the world is spiky (rather than flat), Richard Florida, one of the world's leading urbanists, illustrates that only a few top tier cities drive the world's economy (Florida, 2005). Clearly, under ordinary economic conditions, these "growing peaks" are responsible for huge productivity and monetary gains. However, would these megaregions, and the areas that depend on them, withstand future connectedness disruptions due to extreme isolation measures? Are not these regions more vulnerable to these types of black swan consequences? They are indeed - Van Assche and Warin (2019) recognize that even though IB scholars have produced deep knowledge about global supply chain management, there is a need to develop policy insights to assess the broader social ramifications.

Perez-Batres and Treviño (2020) demonstrated a positive relationship between population density (in 50+ countries) and COVID-19 cases and deaths in proportional terms. Adler, Florida, and Hartt (2020) noted that large urban centers, or megaregions, are particularly vulnerable to pandemics. For example, in the continental United States, the least densely populated states of Wyoming and Montana are also among the least affected by Covid-19 (cases/1 million; deaths/ 1 million). Thus, our advice on placing these regional supply chains in low population areas aims to decrease exposure and vulnerability to extreme isolation measures.

\section{INCENTIVES}

Under ordinary conditions, globalization pressures demand a comparative advantage approach from global supply chain networks. In contrast, black swans' extreme disruptions planning should provide them with a large incentive to develop real (physical) options in low population density areas to maintain production viability. Kadarusman (2020) lamented that one of the main barriers to global value chains' success in small regions is the low price received by 
local members of the chain. This is an expected outcome, given that global supply chain managers follow profit maximization practices while paying less attention to organizational survival.

According to our proposed logic, however, global supply chains would be more likely to transfer some of their profits to local members to build a strong real options "insurance" portfolio to enhance their survival likelihood. Moreover, the strength of our rationale is cemented in an alignment of interest rationale between governments and corporations. Both have an inherent interest in enhancing the probability of their survival by avoiding global supply chain systemic disruptions, resulting in massive employee layoffs, which could beget the technical bankruptcy of governments and global supply chains worldwide. Governments would increase job creation by offering global supply chains access to qualified human resources through regional development. Additionally, global supply chain managers would see the suboptimal international logistic protocol as an appealing trade-off for gaining superior regional and local embeddedness in their areas of operation. We contend that avoiding the scarcity of essential products and services, which could even lead to civil unrest, would be a powerful incentive for both parties to initiate a real options structure.

Moreover, the real options rational is not without precedent in the international business literature. Even if not fully aware, multinational organizations continuously exercise opportunities (real options) to move and redeploy resources across country lines (Ioulianou, Leiblein, \& Trigeorgis, 2020).

\section{CONTRIBUTION}

Our paper calls for developing a culture of anticipating black swan consequences rather than reacting to them. In doing so, we advance the notion of a real options hedging solution. The novelty of our prescription is twofold: (1) It brings attention to the value of anticipating risks and uncertainties by considering less exposed and vulnerable regions. (2) More importantly, it recognizes a change in the relationship's dynamic between global and regional producers. Upon realizing that their survival may be at stake, global supply chain networks may be more willing to transfer rents to their smaller local counterparts.

Our arguments heed Doh and Mezias' (2019) warning about the urgency to recognize the significance of globalization disruptions (this is especially pressing under black swan scenarios) and the need to solve the specific challenges of economic integration in this century. Likewise, considering Kobrin's (2019) reflections on the notion of hyperglobalization, our proposal is not a call to deglobalize. On the contrary, it calls for large global supply chains to embed themselves deeper into the countries' social fabric in which they operate. Lastly, these lines should inspire modern universities to deliver actionable knowledge and the necessary human capital to facilitate social development efforts across regions.

\section{ACKNOWLEDGMENTS}

We express our gratitude to Dr. Mezias, Dr. Newburry, and the anonymous reviewers, who provided excellent guidance throughout the process. Likewise, we are grateful to Tony Perez for his ideas on earlier versions of this manuscript.

\section{ABOUT THE AUTHORS}

Luis A. Perez-Batres (perez1la@cmich.edu) is a graduate of Texas A\&M University (PhD), the University of Illinois at Urbana-Champaign (MS), and Monterrey Tech-Campus Laguna (BS). He is a Professor of Management, Administrative Liaison for Strategic Envisioning, two-term Department Chair, and Presidential Fellow at Central Michigan University. At the University of Michigan's Erb Institute, Luis served as a Faculty Affiliate and Visiting Scholar. His research rests at the interplay of IB and sustainability and has been funded by the Department of Education.

Len J. Treviño is a graduate of Indiana University $(\mathrm{PhD}$; MBA), and the University of Notre Dame (BBA). He is the SBA Communications Distinguished Professor of International Business and Director of International Business Programs at Florida Atlantic University. He is the President of Iberoamerican Academy of Management. His research focuses on the multinational enterprise, including FDI and internationalization strategies. He has published in Journal of International Business Studies, Journal of Management, Journal of World Business and other top management and international business journals.

Submitted: September 03, 2020 EST, Accepted: October 23, 2020 EST 


\section{REFERENCES}

Adler, P., Florida, R., \& Hartt, M. 2020. Mega Regions and Pandemics. Tijdschrift voor economische en sociale geografie, 111(3): 465-481.

Desilus, B. 2020. How the COVID-19 will redefine the Global Supply Chains. Revista Latinoamericana de Investigación Social, 3(1): 5-8.

Doh, J., \& Mezias, J. M. 2019. Special Issue Introduction and Commentary on Trade and Economic Diplomacy. AIB Insights, 19(1): 10-11.

Epstein, L. G. 1999. A definition of uncertainty aversion. The Review of Economic Studies, 66(3): 579-608.

Florida, R. 2005. THE WORLD IS SPIKY Globalization has changed the economic playing field, but hasn't leveled it. Atlantic Monthly, 296(3): 48.

Ioulianou, S. P., Leiblein, M. J., \& Trigeorgis, L. 2020. Multinationality, portfolio diversification, and asymmetric MNE performance: The moderating role of real options awareness. Journal of International Business Studies. https://doi.org/10.1057/ s41267-020-00357-3.
Kadarusman, Y. B. 2020. The Impact of Entrepreneurship on Economic Performance in Indonesia. Economics and Finance in Indonesia, 66(Juni): 1-10.

Kobrin, S. J. 2019. Make internationalism great again: The AIB in an age of populist nationalism. AIB Insights, 19(1): 12-15.

Lewis, M. 2011. The big short: Inside the doomsday machine. Penguin UK.

Lowenstein, R. 2000. When genius failed: The rise and fall of Long-Term Capital Management. Random House trade paperbacks.

Perez-Batres, L. A., \& Treviño, L. J. 2020. Exposure, Black Swans, and Real Options. http://one.aom.org/co vid-19-insights-from-business-sustainability-scholar s/perez-batres-and-trevino-covid19-insights.

Taleb, N. N. 2007. The black swan: The impact of the highly improbable, vol. 2). Random house.

Van Assche, A., \& Warin, T. 2019. Global value chains and economic diplomacy. AIB Insights, 19(1): 16-19. 